\title{
ZRÓŻNICOWANIE PRZESTRZENNE DOCHODÓW WŁASNYCH BUDŻETÓW GMIN W POLSCE W LATACH 2007-2015
}

\section{Wprowadzenie}

Działalność podmiotów i jednostek organizacyjnych sektora publicznego na poziomie regionalnym i lokalnym w warunkach gospodarki rynkowej jest ściśle powiązana i uwarunkowana ogólną sytuacją makroekonomiczną oraz własnymi możliwościami gospodarowania w ramach przypisanych zadań. Najważniejszymi czynnikami oddziałującymi na zakres i skuteczność realizacji zadań samorządu terytorialnego są czynniki o charakterze finansowym, co w praktyce oznacza konieczność przygotowania określonych scenariuszy działania w ramach gospodarki budżetowej poszczególnych jednostek. W warunkach gospodarki rynkowej wspomniane podmioty i jednostki organizacyjne, zaliczane do sektora publicznego, utrzymały swoją pozycję w strukturze gospodarki i społeczeństwa, a w wielu zakresach przedmiotowych ich znaczenie wyraźnie się zwiększyło. W nowych warunkach ustrojowych bardzo ważne miejsce zajęło zapewnianie właściwych, wydajnych i stabilnych źródeł finansowania zadań, jakie wspomniana grupa podmiotów realizuje na rzecz zróżnicowanych grup społecznych.

W ramach opracowania za cel badań przyjęto analizę i ocenę sytuacji finansowej gminnych jednostek samorządu terytorialnego w Polsce w latach 2007-2015. Artykuł stanowi kontynuację szerzej zakrojonych badań prowadzonych od roku 2004, obejmujących zmiany w zakresie gospodarki budżetowej jednostek samorządu terytorialnego w Polsce, a w szczególności badań dochodów oraz wydatków budżetowych. Z uwagi na obszerny materiał empiryczny w artykule analizie poddano zmiany w poziomie dochodów ogółem oraz dochodów własnych gmin w podziale na zróżnicowane kategorie dochodów Polsce w latach 2007-2015, w tym także dochodów, których wartość wynika wprost z profilu społeczno-gospodarczego

* Kolegium Ekonomiczno-Społeczne, Szkoła Główna Handlowa w Warszawie. 
poszczególnych jednostek samorządu terytorialnego. Dlatego też zgodnie z przyjętą formułą prezentowania wyników więcej miejsca poświęcono dochodom, które uzyskiwały gminy z tytułu podatku od nieruchomości oraz w pewnym zakresie $\mathrm{z}$ tytułu podatku rolnego.

Wyniki badań empirycznych przeprowadzonych w ciągu ostatnich lat wskazują, że wyraźnie zwiększyła się wartość dochodów budżetowych. Wyniki te wykazały dużą stabilność dochodów budżetowych i co za tym idzie poprawę samodzielności finansowej gminnych jednostek samorządu terytorialnego. W zestawieniu $\mathrm{z}$ wydatkami jednostek samorządu terytorialnego okazuje się, że często szybki wzrost dochodów budżetowych nie zawsze pozwalał na sfinansowanie niezbędnych zadań w ujęciu bieżącym oraz na podjęcie ważnych inwestycji. Istotną rolę w kształtowaniu budżetu gminnych jednostek samorządu terytorialnego zaczęły odgrywać i nadal odgrywają środki pochodzące z budżetu Unii Europejskiej. Dzięki tym środkom stało się możliwe podniesienie stopy inwestycji realizowanych przez samorządy. Planowany szeroki zakres projektów modernizacyjnych, związanych z chęcią szybkiego łagodzenia dysproporcji rozwojowych, nawet w warunkach szybkiego wzrostu dochodów budżetowych nie zawsze mógł być utrzymany. Z powyższych względów cykliczne badania ilościowe budżetów gminnych jednostek samorządu terytorialnego znajdują swoje pełne uzasadnienie.

W trakcie badań prowadzonych przez Zakład Zarządzania w Sektorze Publicznym w Katedrze Rozwoju Regionalnego i Przestrzennego zgromadzono bardzo obszerny i szczegółowy zasób informacji źródłowych, które umożliwiły przeprowadzenie szerokich, pogłębionych, wieloprzekrojowych badań sytuacji dochodowej budżetów gminnych jednostek samorządu terytorialnego. Uzyskane rezultaty cząstkowe są przedmiotem dalszych analiz, których wyniki będą sukcesywnie publikowane. W artykule przedstawiono jedynie wybrane wątki, które wydają się mieć znaczenie dla oceny zmian sytuacji dochodowej budżetów gmin w Polsce w latach 2007-2015.

\section{Charakterystyka dochodów własnych gmin w Polsce w latach 2007-2015}

W latach 2007-2015 sytuacja w zakresie dochodów budżetowych gminnych jednostek samorządu terytorialnego charakteryzowała się stosunkowo dużą dynamiką, choć niekiedy obserwowano różnokierunkową zmienność w poziomie dochodów w poszczególnych latach objętych analizą. Należy podkreślić, że w okresie 2007-2015 suma dochodów budżetowych gminnych jednostek samorządu terytorialnego w ujęciu 
wojewódzkim znacząco wzrosła ${ }^{1}$. Warto zwrócić uwagę na sytuację województw pomorskiego oraz łódzkiego, gdzie omawiane dochody wzrosły o 59,7\%, sytuację województw dolnośląskiego i lubuskiego, gdzie odnotowano wzrost odpowiednio na poziomie $58,5 \%$ oraz $58,7 \%$, a także województw małopolskiego, podkarpackiego i lubelskiego, gdzie wzrost dochodów wyniósł nieco powyżej 57\%. Oznacza to, że w tych województwach odnotowano relatywne wysokie średnioroczne tempo wzrostu dochodów budżetowych gminnych jednostek samorządu terytorialnego, które kształtowały się na poziomie od 5,0\% do 6,0\%, jedynie w województwach opolskim, lubuskim oraz dolnośląskim średnioroczne tempo wzrostu dochodów budżetowych gmin w wymienionych województwach było niższe i wyniosło odpowiednio $4,1 \%, 4,5 \%$ i $4,8 \%$.

Jeśli chodzi o przyczyny takiej sytuacji, to należy zwrócić uwagę na w zasadzie proporcjonalny wzrost dochodów budżetowych gmin, powiązany z regulacjami ustawowymi, uprawniającymi gminy do systemowego kształtowania wysokości podatków i opłat lokalnych, a także systemowego rozwiązania sprawy udziału gmin w dochodach stanowiących dochody budżetu państwa. Systemowe rozwiązania dotyczyły również subwencjonowania zadań, zwłaszcza w zakresie oświaty i wychowania. Zróżnicowanie sytuacji dochodowej poza rozwiązaniami o charakterze systemowym wiązało się z potencjałem społeczno-gospodarczym i możliwością generowania dochodów brutto przed opodatkowaniem w przedsiębiorstwach, co w naturalny sposób prowadziło do różnic w poziomie dochodów budżetowych gmin w poszczególnych regionach. Dlatego też mając na uwadze zróżnicowanie sytuacji społeczno-gospodarczej gmin i tym samym zróżnicowanie sytuacji dochodowej budżetów jednostek samorządu terytorialnego, można uznać, że występujące różnice w poziomie dochodów oraz dynamika zmian tych dochodów budżetowych gmin jest zjawiskiem obiektywnym.

Jak wynika z przeprowadzonych badań, największy poziom dochodów w roku 2007 odnotowano w województwie mazowieckim - 18,5 mld zł. Dochody w tym województwie były wielokrotnie większe niż dochody budżetów gmin w wielu pozostałych województwach. Przykładowo w województwie mazowieckim dochody gmin były ponad 7-krotnie wyższe niż w województwach opolskim i lubuskim. Podobna sytuacja miała miejsce w województwach świętokrzyskim i podlaskim, podczas gdy dochody w województwie mazowieckim były ponad 6-krotnie wyższe.

\footnotetext{
1 W artykule wyniki badań są prezentowane w układzie wojewódzkim. Używane jest zamiennie w stosunku do słowa „województwo” słowo „region”, które na potrzeby prowadzonej analizy uznane zostały za synonimy. W istocie używane słowa „województwo" i „region” odpowiadają pojęciu zawartemu w art. 1 Ustawy z dnia 5 czerwca 1998 r. o samorządzie województwa, DzU 1998, nr 91, poz. 576 z późn. zm., zgodnie z którym „Ilekroć w ustawie jest mowa o województwie lub samorządzie województwa, należy przez to rozumieć regionalną wspólnotę samorządową oraz odpowiednie terytorium”.
} 
W odniesieniu do pozostałych województw w roku 2007 dochody gmin ogółem kształtowały się na stosunkowo niskim poziomie $\mathrm{w}$ porównaniu $\mathrm{z}$ dochodami gmin województwa mazowieckiego. Nie ulega wątpliwości, że na taki obraz finansów publicznych na poziomie gmin ogromny wpływ miała sytuacja miasta stołecznego Warszawy. W roku 2007 dochody budżetowe Warszawy stanowiły 52,8\% ogółu dochodów budżetów gmin województwa mazowieckiego. W roku 2011 udział ten kształtował się na poziomie 50,0\%, natomiast w roku 2015 na poziomie $51,2 \%$. Stosunkowo wysokie dochody gmin ogółem odnotowano także w województwach śląskim, wielkopolskim oraz dolnośląskim. Szczegółowe dane ilustrujące poziom oraz zmiany wielkości dochodów budżetowych gmin w ujęciu wojewódzkim przedstawiono w tabeli 1.

Tabela 1. Dochody ogółem budżetów gmin oraz m. Warszawy w układzie wojewódzkim (w mln zl)

\begin{tabular}{|l|r|r|r|r|r|r|r|r|c|}
\hline \multicolumn{1}{|c|}{ Wyszczególnienie } & \multicolumn{1}{|c|}{2007} & \multicolumn{1}{c|}{2008} & \multicolumn{1}{c|}{2009} & \multicolumn{1}{c|}{2010} & 2011 & 2012 & 2013 & 2014 & 2015 \\
\hline Łódzkie & 6317,3 & 6984,4 & 7292,6 & 7729,4 & 8096,5 & 8572,7 & 9326,1 & 9449,6 & 10090,6 \\
\hline Mazowieckie & 18497,2 & 19773,8 & 19925,7 & 21124,7 & 22550,7 & 23876,9 & 24400,5 & 26788,4 & 27932,9 \\
\hline $\begin{array}{l}\text { Mazowieckie } \\
\text { (bez m. Warszawy) }\end{array}$ & 8725,4 & 9516,8 & 9809,0 & 10677,8 & 11282,1 & 11935,9 & 12177,8 & 13007,7 & 13619,2 \\
\hline $\begin{array}{l}\text { Podregion 28 } \\
\text { - m. Warszawa }\end{array}$ & 9771,8 & 10257,0 & 10116,7 & 10446,9 & 11268,5 & 11941,0 & 12222,7 & 13780,8 & 14313,7 \\
\hline Małopolskie & 8558,3 & 9207,4 & 9735,8 & 10837,0 & 11206,9 & 11449,5 & 11812,3 & 12590,4 & 13140,7 \\
\hline Śląskie & 12714,8 & 13705,1 & 13962,3 & 15209,7 & 15838,0 & 16392,3 & 17249,6 & 18560,4 & 18838,5 \\
\hline Lubelskie & 4876,0 & 5316,9 & 5581,2 & 6290,9 & 6753,6 & 7142,5 & 7351,3 & 7671,5 & 7670,7 \\
\hline Podkarpackie & 4915,2 & 5377,4 & 5621,6 & 6628,7 & 6744,4 & 6834,1 & 7046,9 & 7421,6 & 7457,7 \\
\hline Podlaskie & 2861,3 & 3147,0 & 3547,5 & 3843,3 & 4036,0 & 4222,7 & 4283,8 & 4817,6 & 4510,3 \\
\hline Świętokrzyskie & 2855,9 & 3177,2 & 3480,9 & 4097,4 & 4133,8 & 4109,0 & 4234,7 & 4388,8 & 4486,7 \\
\hline Lubuskie & 2641,6 & 2669,4 & 2874,1 & 3071,2 & 3141,4 & 3244,7 & 3440,2 & 3626,7 & 3755,9 \\
\hline Wielkopolskie & 8730,8 & 9570,6 & 9704,2 & 10347,9 & 10987,5 & 11713,6 & 11905,2 & 12454,3 & 13383,0 \\
\hline Zachodniopomorskie & 4532,6 & 4912,4 & 5063,8 & 5291,0 & 5696,3 & 6242,2 & 6493,3 & 6796,1 & 7192,8 \\
\hline Dolnośląskie & 8306,6 & 8535,0 & 8772,9 & 9864,2 & 10542,9 & 11002,0 & 11345,8 & 11701,6 & 12048,8 \\
\hline Opolskie & 2451,2 & 2596,5 & 2634,9 & 2905,5 & 2969,2 & 3099,6 & 3140,3 & 3281,3 & 3374,5 \\
\hline Kujawsko-pomorskie & 5359,9 & 5907,0 & 6016,2 & 6448,6 & 6807,1 & 7319,3 & 7645,7 & 8064,9 & 8495,9 \\
\hline Pomorskie & 6618,5 & 6945,3 & 6964,5 & 8024,4 & 8366,9 & 9470,4 & 9465,9 & 9840,5 & 10162,6 \\
\hline Warmińsko-mazurskie & 3639,4 & 3936,1 & 4031,5 & 4482,0 & 4819,5 & 4963,0 & 5118,4 & 5355,0 & 5685,7 \\
\hline
\end{tabular}

Źródło: Opracowanie własne na podstawie danych Banku Danych Lokalnych, GUS, Warszawa 2017.

Przeprowadzona analiza dochodów budżetowych gmin wskazuje, że w latach 2007-2015 nastąpiły znaczące pozytywne zmiany w poziomie dochodów. We wszystkich niemal województwach uległy one prawie podwojeniu. W rezultacie 
w sposób istotny poprawiły się możliwości alokacji zasobów publicznych gmin na rzecz realizacji nowych przedsięwzięć inwestycyjnych, co było również szczególnie ważne z punktu widzenia odbiorców usług publicznych. Zmiany w poziomie dochodów wyraźnie poprawiły również sytuację w zakresie realizacji wydatków bieżących gmin.

Jak wynika z badań empirycznych, dochody budżetowe gmin w województwie mazowieckim charakteryzowały się znacznymi dysproporcjami w wielu przekrojach badawczych. Dysproporcje te ujawniały się zarówno w porównaniach międzygminnych na terenie województwa, jak i w porównaniach międzyregionalnych. Jak wspomniano, województwo mazowieckie cechowało się stosunkowo wysokimi średnimi wskaźnikami w zakresie dochodów budżetów jednostek samorządu terytorialnego na poziomie gminnym, przy czym miasto stołeczne Warszawa miało znacznie lepszą sytuację dochodową w porównaniu z gminami z obszaru całego województwa.

Mając na uwadze tę specyficzną sytuację m.st. Warszawy, w badaniu podjęto próbę prezentacji sytuacji w zakresie dochodów budżetowych gmin województwa mazowieckiego, gdzie można by osobno poddać analizie dochody m.st. Warszawy oraz dochody pozostałych gmin województwa. Ujęcie to miało na celu zbadanie sytuacji m.st. Warszawy na tle województwa. Dlatego też na potrzeby analizy w tabeli 1 zaprezentowano dodatkowe wiersze ilustrujące dochody ogółem budżetu gmin w układzie wojewódzkim bez m.st. Warszawy oraz dochody ogółem m.st. Warszawy. Dla lepszego rozpoznania sytuacji w zakresie dochodów gmin województwa mazowieckiego oraz dochodów wybranych gmin w Polsce na rysunku 1 przedstawiono graficznie zmiany dochodów budżetu m.st. Warszawy na tle zmian dochodów budżetów gmin wybranych województw w Polsce w latach 2007-2015.

Jak już wspomniano, potencjał społeczno-gospodarczy Mazowsza jest zdecydowanie lepszy niż potencjał większości województw w Polsce. Wskazuje na to sytuacja dochodowa gminnych jednostek samorządu terytorialnego Mazowsza, w tym m.st. Warszawy. Dochody m.st. Warszawy w całym okresie objętym analizą systematycznie rosły. W roku 2015 osiągnęły poziom 14,3 mld zł, co oznaczało wzrost dochodów o ponad 46\%. Biorąc pod uwagę wskaźniki dochodowe, a także niektóre wskaźniki rozwoju społeczno-gospodarczego, wyraźnie widać, że Warszawa stała się bardzo szybko rozwijającym się obszarem, gdzie wskaźniki poziomu życia mogą być porównywane z wieloma miastami podobnej wielkości w Europie².

2 K. Jarosiński, G. Maśloch, Analiza i ocena wskaźnika PPS w wybranych miastach Unii Europejskiej wobec celów rozwoju zawartych w Strategii Europa 2020, [w:] Zarzadzanie i finanse podmiotów sektora publicznego, pr. zb. pod red. K. Jarosińskiego, „Monografie i Opracowania” nr 595, Oficyna Wydawnicza SGH, Warszawa 2014, s. 89-105. 
Rysunek 1. Dochody ogółem budżetów gmin oraz m.st. Warszawy w układzie wybranych województw (w mln zł)

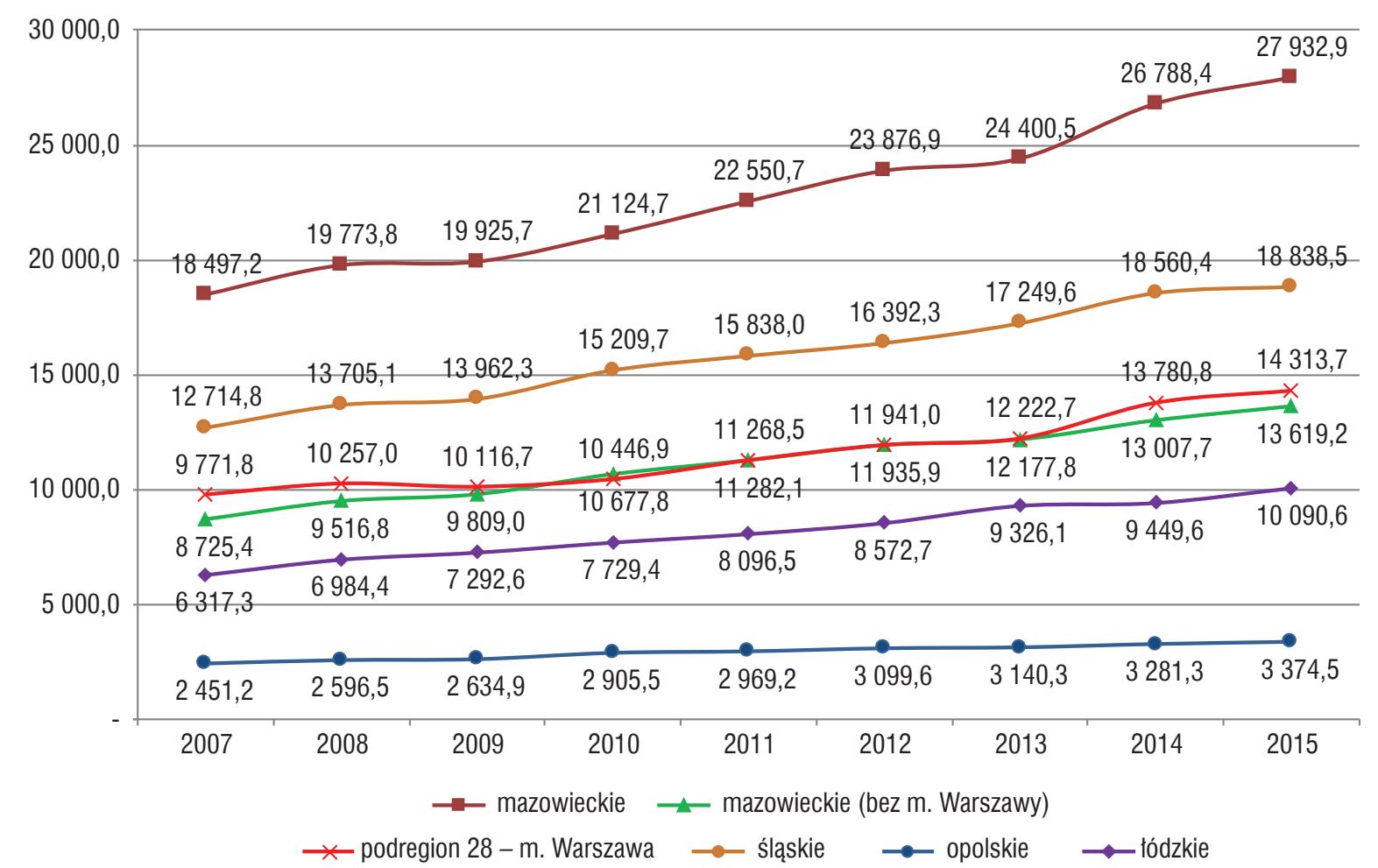

Źródło: Opracowanie własne na podstawie danych z tabeli 1.

Istotną kategorią strumieni pieniężnych kształtujących dochody budżetowe gmin ogólem były dochody własne, określone w art. 4 Ustawy z dnia 13 listopada 2003 r. o dochodach jednostek samorządu terytorialnego ${ }^{3}$. W podjętym badaniu przeprowadzono analizę wszystkich strumieni tworzących dochody własne budżetów gmin, w artykule przedstawiono jednak tylko niektóre z nich. Wyniki te częściowo przedstawiono w tabeli 2. Dane źródłowe wskazują, że w latach 2007-2015 podkreślany wcześniej wyraźny wzrost dochodów budżetowych ogółem był głównie związany ze wzrostem dochodów własnych. W tej grupie dochodów w omawianym okresie we wszystkich regionach odnotowano prawie dwukrotny wzrost tej kategorii dochodów.

Na wzrost dochodów miały wpływ dwie grupy czynników. Po pierwsze, należy zwrócić uwagę na regulacje prawne systemowo zakreślające uprawnienia jednostek samorządu terytorialnego do ustalania wysokości zobowiązań w zakresie podatków i opłat. Takie uprawnienia posiadają jednostki samorządu terytorialnego w zakresie ustalania stawek przy naliczaniu podatku od nieruchomości przy zachowaniu

3 DzU 2003, nr 203, poz. 1966 z późn. zm. 
ustalonego przez ustawę przedziału zmienności stawki, przy czym warto zwrócić uwagę na zakres zmienności stawek, który miał ustaloną górną granicę zmienności Uprawnienia te miały i mają zatem charakter administracyjny i były wykorzystywane przez organy administracji samorządowej w oparciu o zapisy ustawy. Drugą ważną grupę stanowiły czynniki o charakterze ekonomicznym, a zwłaszcza baza podatkowa, której pochodną stanowiły właśnie strumienie zasilające budżety jednostek samorządu terytorialnego. Można zatem przyjąć, że w zmieniających się warunkach społeczno-gospodarczych rozwój gospodarczy, przy niezmienionych warunkach o charakterze administracyjnym, mógł prowadzić do zwiększenia dochodów budżetowych w gminach.

Tabela 2. Dochody własne budżetów gmin w układzie wojewódzkim (w mln zł)

\begin{tabular}{|c|c|c|c|c|c|c|c|c|c|}
\hline Wyszczególnienie & 2007 & 2008 & 2009 & 2010 & 2011 & 2012 & 2013 & 2014 & 2015 \\
\hline Łódzkie & 3483,3 & 4046,5 & 3865,8 & 4102,5 & 4397,7 & 4774,5 & 5320,1 & 5436,6 & 5724,1 \\
\hline Mazowieckie & 12870,8 & 14075,3 & 13598,1 & 13658,2 & 14304,6 & 14782,3 & 15792,1 & 17189,6 & 18231,9 \\
\hline Małopolskie & 4373,3 & 4805,1 & 4879,3 & 4967,9 & 5436,8 & 5617,8 & 6086,8 & 6537,4 & 6864,2 \\
\hline Śląskie & 7524,6 & 8871,9 & 8560,4 & 9010,7 & 9178,6 & 9499,1 & 10009,8 & 10818,4 & 11227,8 \\
\hline Lubelskie & 1925,9 & 2266,3 & 2127,9 & 2284,4 & 2517,5 & 2681,2 & 2837,5 & 3143,4 & 3219,1 \\
\hline Podkarpackie & 1846,7 & 2256,6 & 2150,8 & 2299,5 & 2519,0 & 2620,3 & 2787,1 & 3058,1 & 3152,6 \\
\hline Podlaskie & 1250,4 & 1482,7 & 1516,3 & 1582,7 & 1781,1 & 1899,5 & 1991,6 & 2418,9 & 2199,9 \\
\hline Świętokrzyskie & 1190,8 & 1429,4 & 1455,4 & 1605,9 & 1667,8 & 1737,8 & 1810,1 & 1905,7 & 2002,3 \\
\hline Lubuskie & 1318,0 & 1426,7 & 1360,3 & 1439,0 & 1594,2 & 1659,9 & 1818,2 & 1931,9 & 2066,2 \\
\hline Wielkopolskie & 4677,6 & 5452,1 & 5396,3 & 5685,7 & 6023,9 & 6368,2 & 6558,2 & 6995,3 & 7352,6 \\
\hline Zachodniopomc & 2524,6 & 2858,5 & 2834,7 & 2900,2 & 3064,0 & 3422,9 & 3693,9 & 3899,6 & 4203,4 \\
\hline Dolnośląskie & 5206,5 & 5649,0 & 5571,2 & 6029,4 & 6467,7 & 6794,4 & 7139,7 & 7430,6 & 7681,4 \\
\hline Opolskie & 1260,2 & 1452,1 & 1356,4 & 1451,8 & 1524,4 & 1613,3 & 1714,2 & 1831,2 & 1898,3 \\
\hline Kujawsko-pomorskie & 2523,5 & 2990,3 & 2920,8 & 3161,2 & 3335,2 & 3551,2 & 3794,0 & 4154,3 & 4267,8 \\
\hline Pomorskie & 3737,5 & 4126,6 & 3933,6 & 4444,3 & 4547,0 & 4692,6 & 4948,1 & 5386,6 & 5615,2 \\
\hline Warmińsko-mazurskie & 1623,7 & 1874,2 & 1756,8 & 1924,8 & 2082,2 & 2215,6 & 2303,5 & 2467,3 & 2640,3 \\
\hline
\end{tabular}

Źródło: Jak do tabeli 1.

4 Zgodnie z art. 5 ust. 1 Ustawy z dnia 12 stycznia 1991 r. o podatkach i opłatach lokalnych, DzU 1991, nr 9, poz. 31 z późn. zm., rada gminy określa wysokość stawek podatku od nieruchomości, z tym że stawki nie mogą przekroczyć wartości maksymalnych ustalonych w obwieszczeniu ministra finansów Monitor Polski, Dziennik Urzędowy Rzeczypospolitej Polskiej w sprawie górnych granic stawek kwotowych podatków i opłat lokalnych wydawanego dla poszczególnych okresów podatkowych. 
Rysunek 2. Dochody własne budżetów gmin w układzie wojewódzkim (w mln zł)

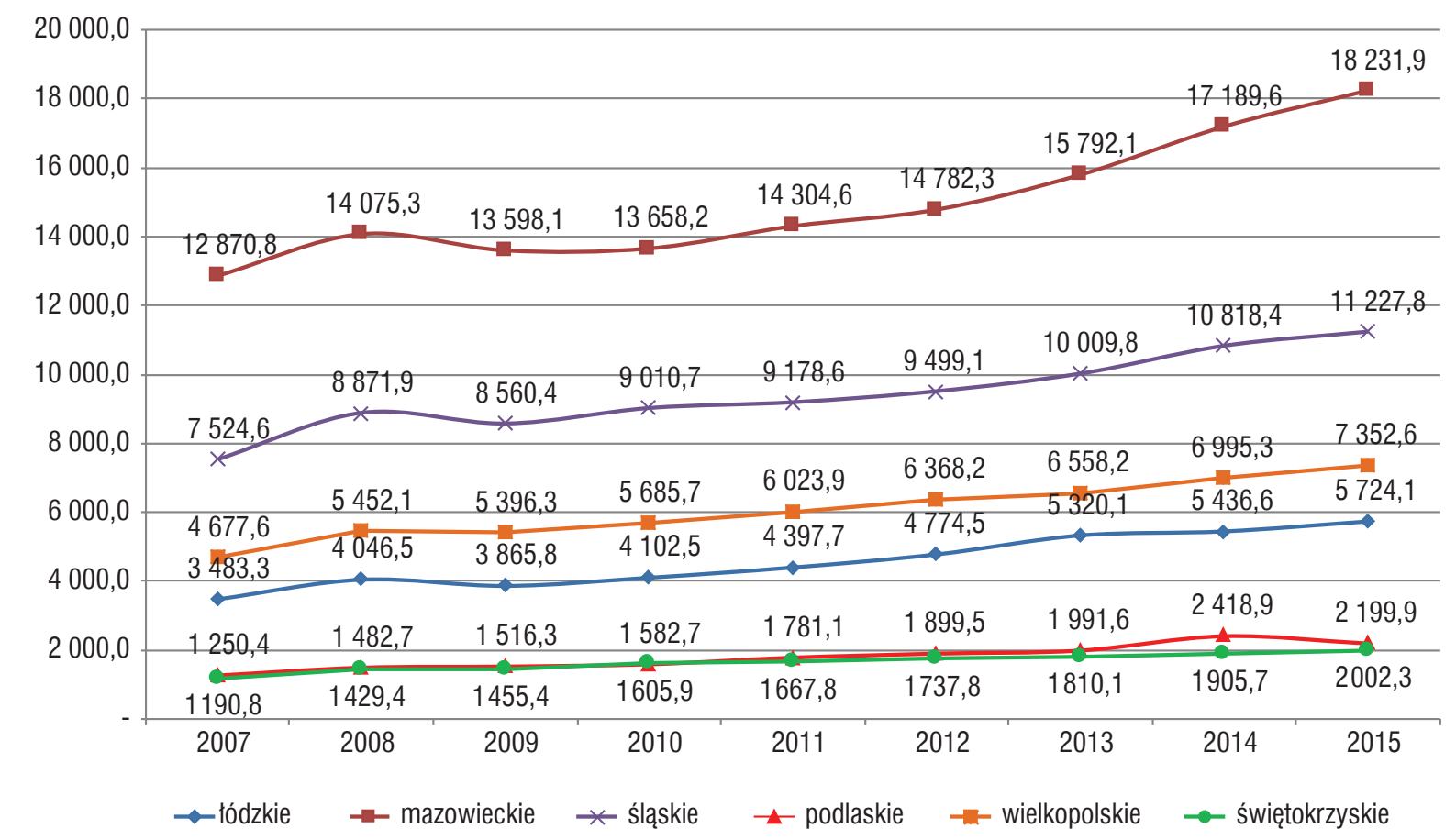

Źródło: Opracowanie własne na podstawie danych z tabeli 2.

Mając na uwadze dochody własne, należy zauważyć, że w latach 2007-2015 nastąpiło zauważalne pogłębienie różnic $\mathrm{w}$ dochodach gmin w układzie wojewódzkim. W roku 2007 największą rozpiętość w dochodach odnotowano pomiędzy województwem mazowieckim a województwami podlaskim i świętokrzyskim, gdzie różnice te wynosiły odpowiednio $11,6 \mathrm{mld}$ zł oraz $11,7 \mathrm{mld}$ zł. W roku 2015 rozpiętość w poziomie dochodów między tymi województwami uległa dalszemu zwiększeniu. $\mathrm{W}$ odniesieniu do wymienionych dwóch województw rozpiętość w poziomie dochodów w stosunku do województwa mazowieckiego wyniosła odpowiednio 16,0 mld zł oraz 16,2 mld zł. Zebrany materiał liczbowy wskazuje, że w latach 2007-2015 dochody własne budżetów jednostek samorządu terytorialnego w układzie wojewódzkim we wszystkich regionach w Polsce wzrosły od 41,7\% w województwie mazowieckim do $75,9 \%$ województwie podlaskim. Nie ulega wątpliwości, że odnotowany wzrost dochodów własnych wyraźnie wskazuje na pojawienie się wyraźnych impulsów rozwojowych, zwłaszcza w województwach najbiedniejszych, gdzie tempo zmian dochodów budżetowych było największe. Analiza danych wskazuje także na pogłębienie się różnic międzyregionalnych, jeśli chodzi o środki, jakimi z roku na rok dysponowały gminy. Jeśli chodzi o wartościowe porównania dochodów własnych budżetów gmin w układzie wojewódzkim, dominującą pozycję w Polsce zajmowało województwo mazowieckie. Przyczyną tego stanu była i nadal pozostaje szczególna sytuacja 
dochodowa miasta stołecznego Warszawy, która przejawia się wyjątkowo dobrymi możliwościami generowania dochodów w sferze realnej i kreowania zróżnicowanych form rozwoju. Jednocześnie, o czym wspomniano, obserwowano relatywnie niższe dochody własne większości gmin województwa mazowieckiego.

O ile w pewnym zakresie różnice w poziomie dochodów własnych gmin w układzie województw w ujęciu krótkookresowym mogą być uznane za zjawisko zrozumiałe z uwagi na występowanie licznych czynników o charakterze obiektywnym, te bowiem krótkookresowo kształtują bazę dochodową gmin w poszczególnych regionach, o tyle w ujęciu wieloletnim pogłębiające się rozwarstwienie dochodów gmin w ujęciu wojewódzkim może budzić wątpliwości, czy aby mamy do czynienia $\mathrm{z}$ niwelowaniem różnić $\mathrm{w}$ poziomie rozwoju, czy też może z pogłębianiem się tych różnic. Obok już wspomnianego zróżnicowania potencjału gospodarczego należy także zauważyć różnice w potencjale ludnościowym i odmiennych profilach społeczno-gospodarczych regionów.

Zatem pogłębianie się różnic, które już w okresie bazowym były stosunkowo duże, a w kolejnych latach uległo dalszemu zwiększeniu, nie może być w pełni uznane za dobry kierunek procesu budowy spójności społeczno-gospodarczej w wymiarze regionalnym. Należy pamiętać, że dysproporcje o charakterze międzyregionalnym mają swoje źródło w występującym zróżnicowaniu w poziomie dochodów gromadzonych przez jednostki samorządu terytorialnego na poziomie lokalnym. Lokalne zróżnicowanie sytuacji społeczno-gospodarczej jest przedmiotem wielu badań, w nawiązaniu do polityki spójności Unii Europejskiej, czego wyrazem są proponowane na poziomie Komisji Europejskiej cele rozwoju społeczno-gospodarczego, a także nowe kierunki łagodzenia dysproporcji i orientacji na rzecz zrównoważonego rozwoju.

Poszerzeniem badań w zakresie dochodów własnych budżetów gmin może być analiza udziałów dochodów własnych w dochodach ogółem budżetów gmin w układzie wojewódzkim. Zgodnie ze zgromadzonym materiałem empirycznym w tabeli 3 przedstawiono obliczone wartości wskaźnika. Najwyższy udział dochodów własnych w dochodach gmin ogółem w roku 2007 odnotowano w województwie mazowieckim - 69,6\%. Stosunkowo wysoki udział tej kategorii dochodów odnotowano również w województwie dolnośląskim - 62,7\% oraz w województwach śląskim, pomorskim i zachodniopomorskim, gdzie wynosił odpowiednio $59,2 \%, 56,5 \%$ oraz $55,7 \%$. Równocześnie najgorsza sytuacja w tym zakresie miała miejsce w województwie podkarpackim, gdzie udział dochodów własnych kształtował się na poziomie 37,6\%. Stosunkowo niski udział odnotowano także w województwach lubelskim, świętokrzyskim oraz podlaskim, gdzie wynosił odpowiednio $39,5 \%, 41,7 \%$ oraz $43,7 \%$. 
Tabela 3. Udział dochodów własnych w dochodach ogółem budżetów gmin w układzie wojewódzkim (w \%)

\begin{tabular}{|l|l|l|l|l|l|l|l|l|l|}
\hline \multicolumn{1}{|c|}{ Wyszczególnienie } & 2007 & 2008 & 2009 & 2010 & 2011 & 2012 & 2013 & 2014 & 2015 \\
\hline Łódzkie & 55,1 & 57,9 & 53,0 & 53,1 & 54,3 & 55,7 & 57,0 & 57,5 & 56,7 \\
\hline Mazowieckie & 69,6 & 71,2 & 68,2 & 64,7 & 63,4 & 61,9 & 64,7 & 64,2 & 65,3 \\
\hline Małopolskie & 51,1 & 52,2 & 50,1 & 45,8 & 48,5 & 49,1 & 51,5 & 51,9 & 52,2 \\
\hline Śląskie & 59,2 & 64,7 & 61,3 & 59,2 & 58,0 & 57,9 & 58,0 & 58,3 & 59,6 \\
\hline Lubelskie & 39,5 & 42,6 & 38,1 & 36,3 & 37,3 & 37,5 & 38,6 & 41,0 & 42,0 \\
\hline Podkarpackie & 37,6 & 42,0 & 38,3 & 34,7 & 37,3 & 38,3 & 39,6 & 41,2 & 42,3 \\
\hline Podlaskie & 43,7 & 47,1 & 42,7 & 41,2 & 44,1 & 45,0 & 46,5 & 50,2 & 48,8 \\
\hline Świętokrzyskie & 41,7 & 45,0 & 41,8 & 39,2 & 40,3 & 42,3 & 42,7 & 43,4 & 44,6 \\
\hline Lubuskie & 49,9 & 53,4 & 47,3 & 46,9 & 50,7 & 51,2 & 52,9 & 53,3 & 55,0 \\
\hline Wielkopolskie & 53,6 & 57,0 & 55,6 & 54,9 & 54,8 & 54,4 & 55,1 & 56,2 & 54,9 \\
\hline Zachodniopomorskie & 55,7 & 58,2 & 56,0 & 54,8 & 53,8 & 54,8 & 56,9 & 57,4 & 58,4 \\
\hline Dolnośląskie & 62,7 & 66,2 & 63,5 & 61,1 & 61,3 & 61,8 & 62,9 & 63,5 & 63,8 \\
\hline Opolskie & 51,4 & 55,9 & 51,5 & 50,0 & 51,3 & 52,0 & 54,6 & 55,8 & 56,3 \\
\hline Kujawsko-pomorskie & 47,1 & 50,6 & 48,5 & 49,0 & 49,0 & 48,5 & 49,6 & 51,5 & 50,2 \\
\hline Pomorskie & 56,5 & 59,4 & 56,5 & 55,4 & 54,3 & 49,5 & 52,3 & 54,7 & 55,3 \\
\hline Warmińsko-mazurskie & 44,6 & 47,6 & 43,6 & 42,9 & 43,2 & 44,6 & 45,0 & 46,1 & 46,4 \\
\hline
\end{tabular}

Źródło: Jak do tabeli 1.

W kolejnych latach, jeśli chodzi o analizowane relacje dochodów, nie nastąpiły istotniejsze zmiany, i tak w roku 2015 najwyższy odsetek odnotowano również w województwie mazowieckim - 65,3\%. Ponadto wysoki udział odnotowano w województwie dolnośląskim - 63,8\% oraz w województwie śląskim - 59,6\%. Najniższy udział omawianej kategorii dochodów w dochodach budżetów gmin w ujęciu wojewódzkim ogółem odnotowano w województwie lubelskim - 42,0\%, następnie w województwie podkarpackim - 42,3\% oraz w województwie świętokrzyskim - 44,6\%. Dane zgromadzone w tabeli 3 dowodzą, że zmiany w strukturze dochodów budżetowych gmin wiążą się ze stosunkowo powolnymi zmianami potencjału społeczno-gospodarczego poszczególnych województw. Ilustrację graficzną omawianych zjawisk przedstawiono na rysunku 3.

W dochodach budżetowych gmin ważne miejsce zajmują dochody z tytułu podatku od nieruchomości. Z uwagi na swoją konstrukcję podatek ten jest dość stabilną formą zasilania budżetów jednostek samorządu terytorialnego, ponieważ jest pochodną poziomu zainwestowania oraz zasobu gruntów niebędących użytkami rolnymi i leśnymi. Podatek ten adresowany jest do właścicieli zróżnicowanych nieruchomości i jest naliczany w zależności od sposobu wykorzystania gruntów niezabudowanych, jak też wielkości oraz struktury zabudowy. 
Rysunek 3. Udział dochodów własnych w dochodach ogółem budżetów gmin w układzie wybranych województw (w \%)

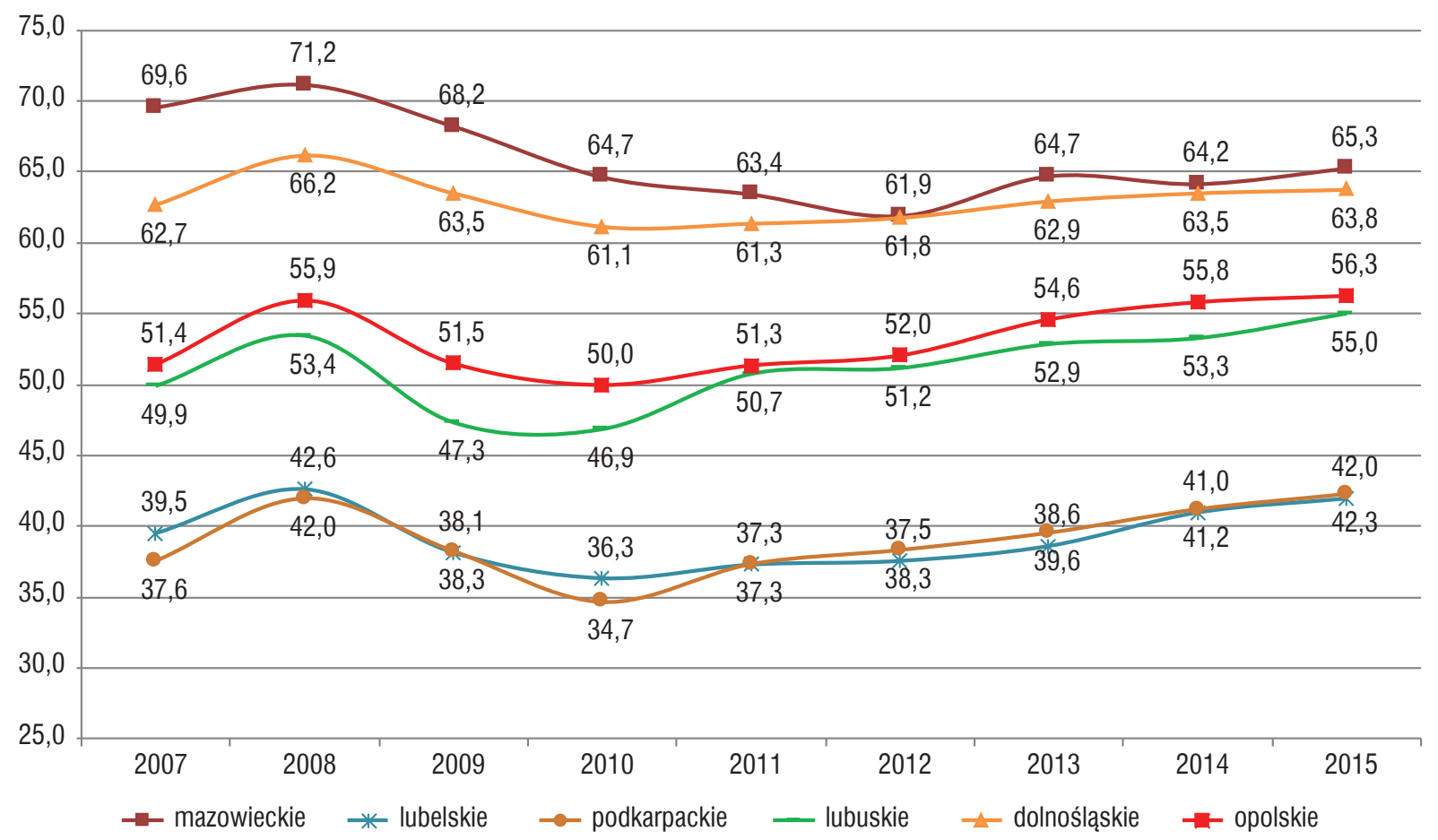

Źródło: Opracowanie własne na podstawie danych Banku Danych Lokalnych, GUS.

W trakcie badań udało się zgromadzić dane źródłowe dotyczące podatku od nieruchomości stanowiące dochody gminnych jednostek samorządu terytorialnego w latach 2007-2015. Wyniki przedstawione zostały w sposób zagregowany jako łączne dochody gmin z tego tytułu w układzie wojewódzkim. W roku 2007 najwyższy poziom dochodów gmin z tytułu podatku od nieruchomości odnotowano w województwie śląskim, następnie w mazowieckim i wielkopolskim. Niski poziom dochodów z tytułu tego podatku odnotowano w województwach świętokrzyskim i podlaskim, odpowiednio 332,4 mln zł oraz 333,3 mln zł. W kolejnych latach 2008-2011 sytuacja taka nadal utrzymywała się. W roku 2011 pod względem najwyższego poziomu dochodów nadal należy wskazać województwo śląskie, a następnie mazowieckie; jeśli chodzi o regiony o najmniejszym poziomie dochodów z tytułu tego podatku, to należy tutaj wymienić ponownie świętokrzyskie - 404,6 mln zł i podlaskie - 428,6 mln zł. W końcowym roku analizy, tj. w roku 2015 we wszystkich województwach odnotowano wzrost dochodów $\mathrm{z}$ tytułu podatku od nieruchomości w porównaniu $\mathrm{z}$ wcześniejszymi okresami badawczymi. W tym roku najwyższy poziom podatku od nieruchomości odnotowano w województwie mazowieckim, a następne w województwie śląskim, odpowiednio 2899,6 mln zł i 2701,9 mln zł. Województwami o najniższych dochodach z tytułu omawianego podatku pozostawały województwa świętokrzyskie oraz podlaskie, odpowiednio 531,6 mln zł i 553,9 mln zł. Warto zatem 
zauważyć, że struktura wojewódzka dochodów z tytułu podatku od nieruchomości w Polsce nie uległa znaczącym zmianom, choć w poszczególnych województwach dochody z tego tytułu w latach 2007-2015 wyraźnie wzrosły. Dane liczbowe charakteryzujące zmiany w poziomie dochodów budżetów gmin w układzie wojewódzkim przedstawiono tabeli 4 .

Tabela 4. Dochody budżetów gmin z tytułu podatku od nieruchomości w układzie wojewódzkim (w mln zł)

\begin{tabular}{|l|r|r|r|r|r|r|r|r|r|}
\hline Wyszczególnienie & \multicolumn{1}{|c|}{2007} & \multicolumn{1}{|c|}{2008} & \multicolumn{1}{|c|}{2009} & \multicolumn{1}{c|}{2010} & \multicolumn{1}{c|}{2011} & \multicolumn{1}{c|}{2012} & \multicolumn{1}{c|}{2013} & \multicolumn{1}{c|}{2014} & \multicolumn{1}{c|}{2015} \\
\hline Łódzkie & 851,8 & 915,9 & 956,3 & 1012,8 & 1099,9 & 1203,0 & 1283,0 & 1340,3 & 1395,7 \\
\hline Mazowieckie & 1825,5 & 1930,5 & 2048,4 & 2207,5 & 2334,8 & 2530,1 & 2705,0 & 2819,4 & 2899,6 \\
\hline Małopolskie & 873,2 & 949,3 & 984,5 & 1027,8 & 1093,5 & 1193,5 & 1270,5 & 1353,3 & 1400,4 \\
\hline Śląskie & 1853,0 & 1975,5 & 2102,4 & 2202,6 & 2350,2 & 2479,8 & 2601,5 & 2659,8 & 2701,9 \\
\hline Lubelskie & 494,4 & 501,9 & 524,0 & 544,4 & 586,9 & 640,3 & 698,6 & 752,3 & 756,7 \\
\hline Podkarpackie & 531,1 & 542,4 & 569,1 & 619,6 & 680,6 & 737,2 & 778,7 & 809,4 & 826,8 \\
\hline Podlaskie & 333,3 & 358,0 & 381,6 & 412,3 & 428,6 & 464,8 & 499,2 & 529,9 & 553,9 \\
\hline Świętokrzyskie & 332,4 & 351,6 & 364,5 & 379,1 & 404,6 & 443,4 & 486,6 & 509,3 & 531,6 \\
\hline Lubuskie & 344,5 & 367,1 & 382,0 & 407,7 & 443,6 & 504,0 & 554,6 & 585,1 & 602,8 \\
\hline Wielkopolskie & 1226,2 & 1288,6 & 1355,8 & 1441,1 & 1544,8 & 1669,3 & 1782,7 & 1866,1 & 1942,8 \\
\hline Zachodniopomorskie & 666,4 & 712,6 & 760,8 & 804,7 & 873,9 & 962,1 & 1057,1 & 1068,4 & 1115,2 \\
\hline Dolnośląskie & 1161,5 & 1222,6 & 1304,0 & 1382,7 & 1466,3 & 1593,4 & 1696,9 & 1772,2 & 1846,4 \\
\hline Opolskie & 375,2 & 398,1 & 407,9 & 437,7 & 481,1 & 526,6 & 545,1 & 572,1 & 587,7 \\
\hline Kujawsko-pomorskie & 664,3 & 683,6 & 726,3 & 793,1 & 851,3 & 933,3 & 987,0 & 1013,4 & 1050,3 \\
\hline Pomorskie & 785,2 & 838,8 & 895,0 & 981,4 & 1112,1 & 1170,2 & 1196,0 & 1265,2 & 1296,8 \\
\hline Warmińsko-mazurskie & 384,2 & 410,9 & 427,2 & 467,7 & 500,9 & 551,4 & 587,1 & 615,8 & 662,8 \\
\hline
\end{tabular}

Źródło: Jak do tabeli 1.

W latach 2007-2015 nastąpiło wyraźne zróżnicowanie w poziomie dochodów z tytułu podatku od nieruchomości. Odnotowany znaczący przyrost dochodów z tytułu podatku od nieruchomości w części województw w Polsce nastąpił z uwagi na skalę istniejącego zagospodarowania oraz w efekcie oddawania do użytku licznych nowych inwestycji. Jednocześnie $\mathrm{w}$ wielu województwach, zwłaszcza o znaczącym udziale gruntów rolnych i leśnych w powierzchni gruntów ogółem, a także w województwach o stosunkowo niższym poziomie zagospodarowania zanotowano mniejszy wzrost z tytułu tego podatku. Sytuacja ta miała w zasadzie charakter obiektywny, wynikała bowiem z uwarunkowań i czynników, które miały swoje źródło we wcześniejszych okresach historycznych, ukształtowanej wówczas strukturze społeczno-gospodarczej oraz $\mathrm{w}$ warunkach naturalnych, przesądzających niekiedy o profilu rozwoju. Biorąc pod uwagę wymogi wynikające z koncepcji rozwoju zrównoważonego, a także 
przesłanki polityki spójności i związane z tą polityką kierunki rozwoju regionów, można sądzić, że niższe dochody z tytułu podatku od nieruchomości będą mogły być rekompensowane dochodami o innym charakterze. Dla lepszej czytelności zmiany w poziomie dochodów budżetów gmin z tytułu podatku od nieruchomości w układzie wojewódzkim zaprezentowano na rysunku 5.

Rysunek 4. Dochody budżetów gmin z tytułu podatku od nieruchomości w układzie wybranych województw ( $\mathrm{w}$ mln zt)

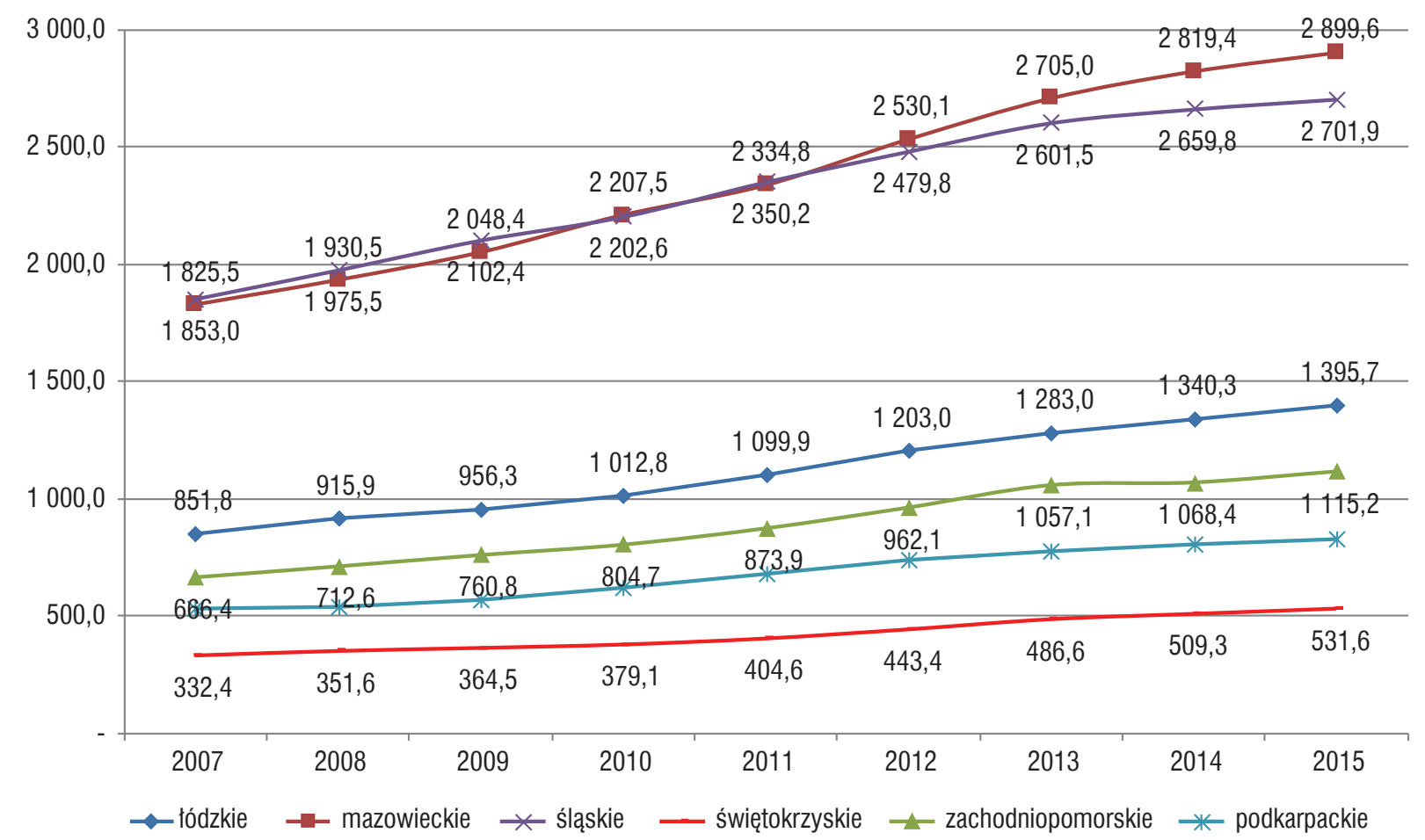

Źródło: Opracowanie własne na podstawie danych z tabeli 4.

Warto także zwrócić uwagę na udział dochodów z tytułu podatku od nieruchomości w dochodach ogółem budżetów gmin w układzie wojewódzkim. W latach 2007-2015 utrzymywały się w poszczególnych województwach różnice jeśli chodzi o ten udział. W roku 2007 stosunkowo najwyższy wskaźnik udziału odnotowano w województwach opolskim, zachodniopomorskim i dolnośląskim, odpowiednio 15,3\%, 14,5\% i 14,3\%, w województwach mazowieckim i lubelskim odnotowano relatywnie najniższe wskaźniki udziału, odpowiednio 9,9\% i 10,1\%. Choć różnice między poszczególnymi regionami są widoczne, to należy uznać, że udział dochodów z tytułu omawianego podatku we wszystkich województwach kształtował się na raczej zbliżonym poziomie. Warto wskazać, że w kolejnych latach 2008-2015 udział omawianego podatku w dochodach budżetowych gmin na poziomie województw ogółem kształtował się w poszczególnych województwach także na zbliżonym poziomie. 
Tabela 5. Udział dochodów z tytułu podatku od nieruchomości w dochodach ogółem budżetów gmin w układzie wojewódzkim (w \%)

\begin{tabular}{|l|r|r|r|r|r|r|r|r|r|}
\hline Wyszczególnienie & 2007 & 2008 & 2009 & 2010 & 2011 & 2012 & 2013 & 2014 & 2015 \\
\hline Łódzkie & 13,5 & 13,1 & 13,1 & 13,1 & 13,6 & 14,0 & 13,8 & 14,2 & 13,8 \\
\hline Mazowieckie & 9,9 & 9,8 & 10,3 & 10,4 & 10,4 & 10,6 & 11,1 & 10,5 & 10,4 \\
\hline Małopolskie & 10,2 & 10,3 & 10,1 & 9,5 & 9,8 & 10,4 & 10,8 & 10,7 & 10,7 \\
\hline Śląskie & 14,6 & 14,4 & 15,1 & 14,5 & 14,8 & 15,1 & 15,1 & 14,3 & 14,3 \\
\hline Lubelskie & 10,1 & 9,4 & 9,4 & 8,7 & 8,7 & 9,0 & 9,5 & 9,8 & 9,9 \\
\hline Podkarpackie & 10,8 & 10,1 & 10,1 & 9,3 & 10,1 & 10,8 & 11,1 & 10,9 & 11,1 \\
\hline Podlaskie & 11,6 & 11,4 & 10,8 & 10,7 & 10,6 & 11,0 & 11,7 & 11,0 & 12,3 \\
\hline Świętokrzyskie & 11,6 & 11,1 & 10,5 & 9,3 & 9,8 & 10,8 & 11,5 & 11,6 & 11,8 \\
\hline Lubuskie & 13,0 & 13,8 & 13,3 & 13,3 & 14,1 & 15,5 & 16,1 & 16,1 & 16,1 \\
\hline Wielkopolskie & 14,0 & 13,5 & 14,0 & 13,9 & 14,1 & 14,3 & 15,0 & 15,0 & 14,5 \\
\hline Zachodniopomorskie & 14,7 & 14,5 & 15,0 & 15,2 & 15,3 & 15,4 & 16,3 & 15,7 & 15,5 \\
\hline Dolnośląskie & 14,0 & 14,3 & 14,9 & 14,0 & 13,9 & 14,5 & 15,0 & 15,1 & 15,3 \\
\hline Opolskie & 15,3 & 15,3 & 15,5 & 15,1 & 16,2 & 17,0 & 17,4 & 17,4 & 17,4 \\
\hline Kujawsko-pomorskie & 12,4 & 11,6 & 12,1 & 12,3 & 12,5 & 12,8 & 12,9 & 12,6 & 12,4 \\
\hline Pomorskie & 11,9 & 12,1 & 12,9 & 12,2 & 13,3 & 12,4 & 12,6 & 12,9 & 12,8 \\
\hline Warmińsko-mazurskie & 10,6 & 10,4 & 10,6 & 10,4 & 10,4 & 11,1 & 11,5 & 11,5 & 11,7 \\
\hline
\end{tabular}

Źródło: Jak do tabeli 1.

W latach 2007-2015 udział dochodów gmin z tytułu podatku od nieruchomości w dochodach ogółem budżetu w układzie wojewódzkim w dwóch województwach uległ nieznacznemu obniżeniu (śląskie, lubelskie), w pozostałych województwach wykazał nieznaczny wzrost, w jednym województwie pozostał na niezmienionym poziomie (kujawsko-pomorskie), choć w tym czasie obserwowano wzrost poziomu dochodów z tego tytułu ogółem. Należy podkreślić, że wskazane spadki udziału miały miejsce przy bezwzględnym wzroście dochodów w tej kategorii. Zjawisko to wiązało się zatem ze zmianą struktury dochodów budżetowych gmin na rzecz innych kategorii dochodów. Wyniki obliczeń oraz ilustrację graficzną zmian wysokości udziału podatku od nieruchomości w dochodach budżetowych gmin w latach 2007-2015 przedstawiono w tabeli 5 oraz na rysunku 5.

$\mathrm{Z}$ uwagi na dużą liczbę gmin w Polsce o profilu wiejskim i miejsko-wiejskim nie można pominąć dochodów $\mathrm{z}$ tytułu podatku rolnego. Podatek rolny jest bowiem ważnym instrumentem gospodarowania ziemią na obszarach wiejskich, choć jego wysokość w stosunku do jednostki obliczeniowej (1 ha) jest stosunkowo niska, jednak podatek ten jest znacząco zróżnicowany w zależności od klasy bonitacyjnej ziemi i jako taki musi być brany pod uwagę przy produkcji rolnej. Warto także zauważyć, 
że dochody z tytułu tego podatku w gminach o wybitnie rolniczym charakterze stanowią ważne źródło dochodów budżetowych.

Rysunek 5. Udział dochodów z tytułu podatku od nieruchomości w dochodach ogółem budżetów gmin w układzie wybranych województw (w \%)

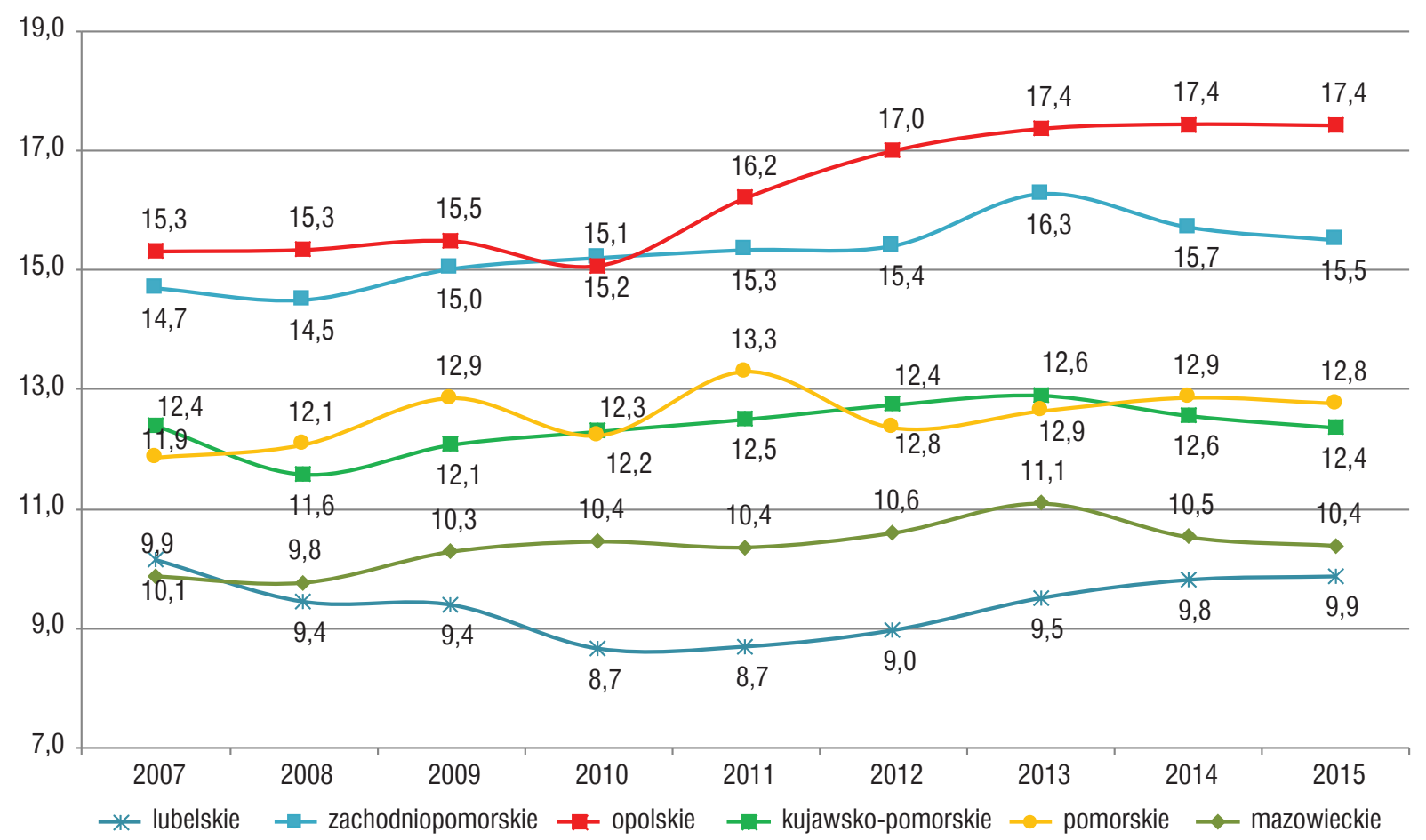

Źródło: Jak do rysunku 3.

W latach 2007-2015 dochody budżetów gmin z tytułu omawianego podatku podlegały znaczącym wahaniom. Początkowo stosunkowo wysokie dochody z tytułu podatku rolnego odnotowano w latach 2008 oraz 2009, jednak w kolejnych latach dochody te uległy obniżeniu, następnie, począwszy od roku 2012, odnotowano dalszy wzrost dochodów z tego tytułu. Należy pamiętać, że największy wpływ na zmiany w wysokości podatku miały stawki podatku rolnego, mające swoją podstawę w mechanizmie ustalania stawek w oparciu o cenę 1 kwintala żyta. Przykładowo w latach 2008 oraz 2009 stawki te dla tzw. hektara przeliczeniowego kształtowały się odpowiednio na poziomie $145,83 \mathrm{zł}$ oraz $139,50 \mathrm{zl}$, zaś dla 1 ha gruntów pozostałych na poziomie $291,45 \mathrm{zl}$ oraz 279,00 zł, natomiast w latach 2014 i 2015 odpowiednio 173,20 zł i 153,43 zł oraz 346,40 zł i 306,85 zł5. Na podatek ten oddziaływały także inne czynniki,

5 Wartości ustalane są przez prezesa GUS i publikowane w komunikatach prezesa Głównego Urzędu Statystycznego w sprawie średniej ceny skupu żyta będącej podstawą do ustalenia podatku rolnego na rok podatkowy. 
jak choćby zmiany powierzchni gruntów wykorzystywanych na cele rolnicze. Dane liczbowe charakteryzujące dochody z tytułu podatku rolnego gminnych jednostek samorządu terytorialnego przedstawiono w tabeli 6 oraz na rysunku 6.

Tabela 6. Dochody budżetów gmin z tytułu podatku rolnego w układzie wojewódzkim (w mln zl)

\begin{tabular}{|l|r|r|r|r|r|r|r|r|r|}
\hline Wyszczególnienie & 2007 & 2008 & 2009 & 2010 & 2011 & 2012 & 2013 & 2014 & 2015 \\
\hline Łódzkie & 53,0 & 70,1 & 68,4 & 54,5 & 58,5 & 80,4 & 85,6 & 85,4 & 84,1 \\
\hline Mazowieckie & 98,4 & 123,2 & 121,6 & 101,7 & 108,3 & 146,1 & 155,9 & 154,8 & 152,5 \\
\hline Małopolskie & 55,3 & 75,9 & 75,9 & 55,4 & 60,3 & 92,0 & 96,1 & 95,3 & 89,9 \\
\hline Śląskie & 35,3 & 51,6 & 50,9 & 35,1 & 37,6 & 61,9 & 65,0 & 63,0 & 57,9 \\
\hline Lubelskie & 98,5 & 115,2 & 115,7 & 109,0 & 114,2 & 140,5 & 149,3 & 150,5 & 151,2 \\
\hline Podkarpackie & 54,1 & 67,4 & 69,6 & 55,6 & 59,8 & 82,1 & 88,0 & 87,2 & 85,7 \\
\hline Podlaskie & 33,2 & 48,3 & 47,6 & 34,8 & 38,2 & 62,4 & 66,5 & 65,9 & 61,4 \\
\hline Świętokrzyskie & 38,7 & 47,2 & 46,4 & 40,5 & 43,1 & 55,2 & 58,4 & 58,2 & 58,7 \\
\hline Lubuskie & 24,3 & 33,1 & 35,1 & 26,2 & 28,0 & 43,2 & 48,0 & 47,3 & 44,5 \\
\hline Wielkopolskie & 86,2 & 111,2 & 115,1 & 93,3 & 100,4 & 141,0 & 151,8 & 154,2 & 151,7 \\
\hline Zachodniopomorskie & 57,9 & 76,9 & 82,1 & 65,4 & 68,4 & 107,8 & 120,7 & 117,5 & 111,4 \\
\hline Dolnośląskie & 75,7 & 105,1 & 103,9 & 79,8 & 86,7 & 139,0 & 151,9 & 149,2 & 137,9 \\
\hline Opolskie & 44,9 & 66,0 & 64,2 & 44,7 & 49,2 & 85,9 & 92,6 & 91,4 & 81,5 \\
\hline Kujawsko-pomorskie & 65,8 & 84,0 & 86,7 & 74,1 & 78,8 & 104,5 & 114,1 & 115,0 & 114,0 \\
\hline Pomorskie & 48,5 & 66,0 & 67,6 & 51,7 & 55,9 & 89,2 & 95,9 & 94,4 & 89,9 \\
\hline Warmińsko-mazurskie & 61,8 & 86,5 & 87,7 & 67,7 & 74,8 & 114,8 & 125,2 & 124,2 & 120,7 \\
\hline
\end{tabular}

Źródło: Jak do tabeli 1.

W roku 2007 udział dochodów z tytułu podatku rolnego w dochodach ogółem budżetów gmin w układzie wojewódzkim nie przekraczał 2\% (województwo lubelskie), w większości województw kształtował się na relatywnie niskim poziomie i oscylował wokół wartości 1\%. W latach 2007-2015 nie odnotowano istotniejszych zmian jeśli chodzi o udział podatku rolnego dochodach ogółem budżetów gmin w układzie wojewódzkim. W ostatnim roku badania, tj. w roku 2015, wskazane wcześniej udziały kształtowały się na zbliżonym poziomie, jedynie w województwie opolskim nastąpił wzrost udziału z 1,8\% w 2004 r. do 2,4\% w roku 2015, a także w województwie warmińsko-mazurskim z 1,7\% do 2,1\%.

Najniższy udział w roku 2007 odnotowano w województwie śląskim (0,3\%), także niski udział odnotowano w województwach mazowieckim oraz małopolskim, odpowiednio 0,5\% i 0,6\%. Mając na uwadze specyfikę tych województw, można by sądzić, że podatek rolny, zwłaszcza w województwie małopolskim, mógłby stanowić większy udział. W województwie mazowieckim natomiast, $\mathrm{z}$ uwagi na silne oddziaływanie 
m.st. Warszawy na poziom dochodów budżetów gmin ogółem, dochody z rolnictwa charakteryzowały się niskim udziałem w ujęciu zagregowanym na poziomie województwa. W roku 2015 udział dochodów z tytułu podatku rolnego kształtował się na podobnym poziomie, jak miało to miejsc w roku 2007. Mając na uwadze ogólny wzrost dochodów, o którym wspomniano już wcześniej, utrzymanie udziałów na zbliżonym poziomie było rezultatem zwiększonych dochodów $\mathrm{z}$ tytułu podatku rolnego, zwłaszcza latach 2012-2015.

Rysunek 6. Dochody budżetów gmin z tytułu podatku rolnego w układzie wybranych województw (w mln zł)

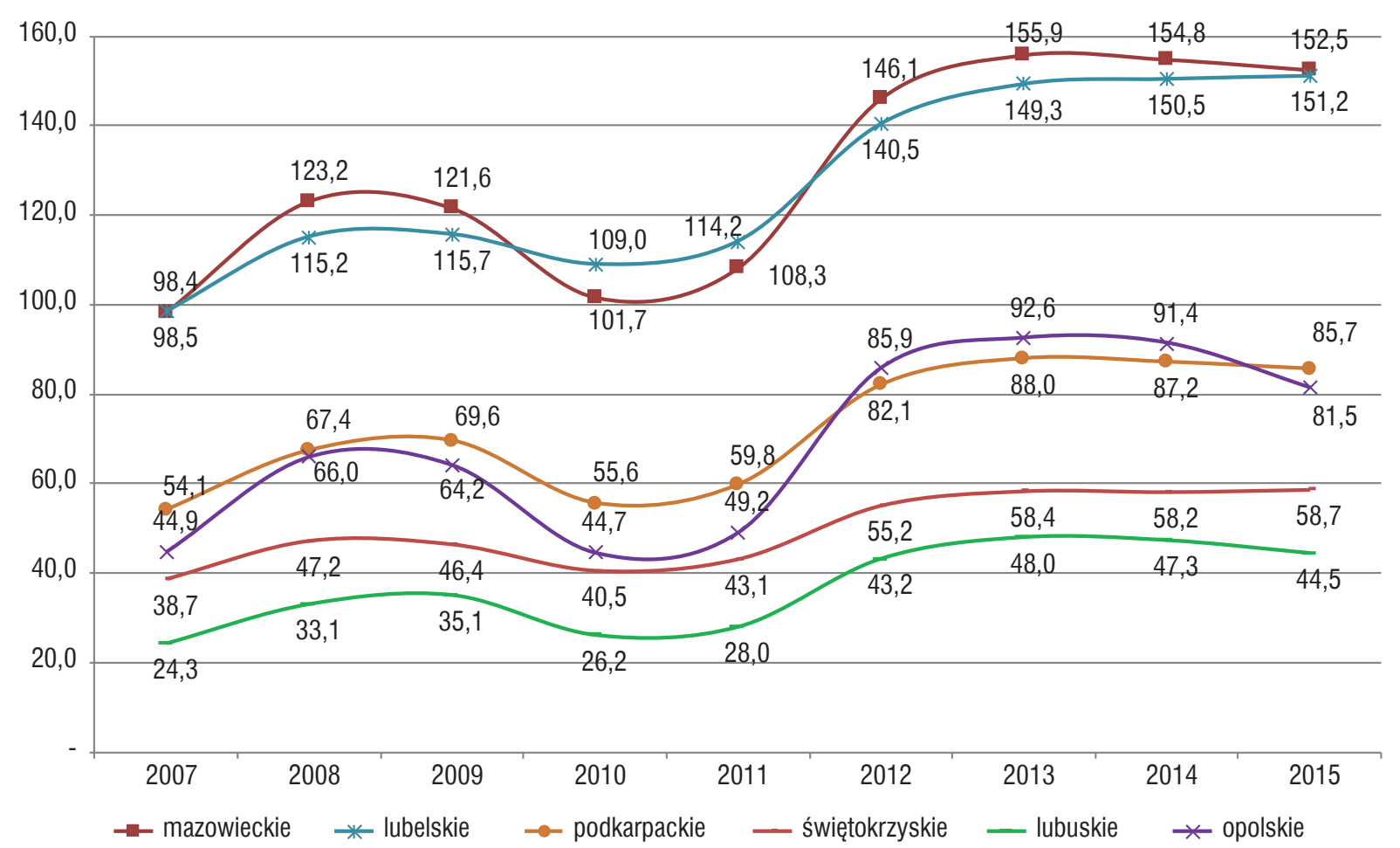

Źródło: Opracowanie własne na podstawie danych z tabeli 6.

Należy sądzić, że w ramach istniejącego systemu naliczania podatku rolnego wzrost dochodów wiązał się ze zmianą statusu gruntów i przekwalifikowywania gruntów rolnych w grunty pozostałe, dla których stawki są znacząco wyższe. Takie podejście co do zasady stanowi podstawę opodatkowania gruntów rolnych zgodnie z kwalifikacją zawartą w ewidencji gruntów i budynków. W myśl tej zasady zmiana kwalifikacji gruntów będzie prowadzić do zmiany zasad ich opodatkowania. Podatek rolny, jak już wspomniano, nie wszędzie odgrywa jednakową rolę jako źródło dochodów budżetowych gminy, jednak zwłaszcza w gminach wiejskich podatek ten może stanowić ważną część w strukturze dochodów własnych. 
Wyniki badań dochodów budżetowych gmin i na tym tle wyniki badań niektórych strumieni dochodów własnych obejmujących lata 2007-2015 wskazują na pogłębianie się różnic w poziomie dochodów. Taka sytuacja miała miejsce nawet wobec uruchomionych mechanizmów wyrównujących i stabilizujących. Pozytywnym zjawiskiem było systematyczne zwiększanie dochodów budżetowych gmin. Oznaczało to, że w analizowanym okresie nastąpiła poprawa warunków jeśli chodzi o realizację zadań z wykorzystaniem własnych zasobów budżetowych. Szybkie i dynamiczne zmiany w zakresie dochodów budżetowych jednostek samorządu terytorialnego dowodzą, że trudno jest przewidzieć kierunki zmian w ujęciu długookresowym. Wydaje się, że rozwiązaniem docelowym stanie się poszukiwanie konsensusu prowadzące do optymalizacji obciążeń podatkowych oraz do lepszego wykorzystania już posiadanych zasobów.

\section{Wnioski}

Zgromadzony materiał empiryczny oraz wyniki badań analitycznych wskazują na występujące zróżnicowanie dochodów budżetowych w latach 2007-2015. W tym czasie dochody budżetowe gmin uległy zwiększeniu w odniesieniu do głównych składowych strumieni dochodów budżetowych. Nastąpiły też znaczące pozytywne zmiany sytuacji budżetowej gminnych jednostek samorządu terytorialnego w ujęciu wojewódzkim. Niemal we wszystkich regionach dochody te uległy podwojeniu. W konsekwencji poprawiły się możliwości realizacji zróżnicowanych zadań publicznych.

Wzrostowi dochodów budżetowych gmin towarzyszyły już wcześniej ujawnione zjawiska, w szczególności utrzymywanie się dysproporcji pomiędzy regionami słabiej rozwiniętymi a regionami o dobrze wykształconym profilu gospodarczym i społecznym. Różnice w poziomie dochodów mogą być uznane za zjawiska normalne, jednak utrwalenie tych różnic w dłuższym okresie może stać się hamulcem rozwojowym regionów słabszych ekonomicznie.

Biorąc pod uwagę dochody własne gmin, należy wskazać, że w latach 2007-2015 nastąpiło zauważalne pogłębienie różnic w dochodach gmin w układzie wojewódzkim. O ile w roku 2007 pomiędzy województwem mazowieckim a podlaskim czy świętokrzyskim różnice te wynosiły odpowiednio 11,6 mld zł oraz 11,7 mld zł, to już w roku 2015 omawiana rozpiętość w poziomie dochodów w stosunku do województwa mazowieckiego wyniosła odpowiednio $16,0 \mathrm{mld}$ zł oraz 16,2 mld zł. W ujęciu krótkookresowym również w stosunku do dochodów własnych różnice mogą być traktowane jako zjawisko normalne, jednak w ujęciu długookresowym rozwarstwienie 
dochodów gmin w ujęciu wojewódzkim może prowadzić do utrwalenia licznych negatywnych zjawisk.

Jeśli chodzi o podatek od nieruchomości, to dochody budżetowe gmin w Polsce z tego tytułu charakteryzowały się dość dużym zróżnicowaniem. Co prawda w roku $2015 \mathrm{w}$ porównaniu z okresami wcześniejszymi we wszystkich regionach nastąpił wzrost wartości podatku od nieruchomości, jednak w rezultacie zachodzących zmian nastąpiło pogłębienie różnic pomiędzy poszczególnymi regionami w Polsce. W 2015 r. najwyższy poziom dochodów z tytułu podatku od nieruchomości odnotowano w województwie mazowieckim - 2899,6 mln zł, jednocześnie regionem o najniższych dochodach $\mathrm{z}$ tytułu omawianego podatku pozostawało województwo świętokrzyskie - 531,6 mln zł.

Biorąc pod uwagę dochody z tytułu podatku rolnego w latach 2007-2015, dochody budżetów gmin podlegały znaczącym zmianom. Stosunkowo wysokie dochody odnotowano w latach 2008 i 2009, w kolejnych latach dochody uległy obniżeniu. Zwyżkę dochodów odnotowano następnie, poczynając od roku 2012. Należy pamiętać, że podatek rolny jest dość specyficzny - jego wysokość ustalana jest w oparciu o mechanizm odwołujący się do ceny 1 kwintala żyta. $Z$ uwagi na powiązania o charakterze ekonomicznym stawki podatku w kolejnych latach mogą podlegać różnokierunkowym zmianom. Jak już zaznaczono, dochody z tytułu tego podatku w gminach o wybitnie rolniczym charakterze odgrywały i będą odgrywać ważną rolę jako źródło dochodów budżetowych gmin.

Wyniki przeprowadzonych badań dochodów budżetowych gmin, dotyczące lat 2007-2015, wskazują na dalsze pogłębienie różnic w poziomie dochodów budżetów gmin ogółem w układzie województw, przy równoczesnym wzroście wartości dochodów. Poprawa sytuacji dochodowej gmin oznaczała wyraźną zmianę warunków ekonomicznych realizacji zadań bieżących oraz finansowania zróżnicowanych przedsięwzięć inwestycyjnych. Warto podkreślić, że zjawiska te wystąpiły w warunkach uruchomienia zróżnicowanych mechanizmów wyrównawczych oraz stabilizacyjnych na bazie polityki spójności Unii Europejskiej. Wyraźny wzrost wielkości dochodów gminnych jednostek samorządu terytorialnego w Polsce był przejawem pozytywnych zmian zachodzących w gospodarce i społeczeństwie, $z$ drugiej jednak strony nastąpiło pogłębienie różnic $\mathrm{w}$ dochodach budżetowych gmin, zagregowanych na poziomie województw. Zjawisko to skłania do zwrócenia większej uwagi na zachodzące procesy oraz skłania do refleksji nad dalszymi celami rozwoju lokalnego i regionalnego w kontekście niwelowania różnic w poziomie życia mieszkańców. Mając na uwadze fakt, że procesy przemian w ramach polityki spójności trwają nadal, należy sądzić, że w perspektywie kolejnych okresów programowania uda się osiągnąć stawiane cele rozwojowe. 


\section{Spatial differences of gmina's budget revenues in Poland between 2007-2015}

The experience of systemic transformation in Poland and the progressing socio-economic development prove that the importance of organizational units classified conventionally as a part of the public sector has increased significantly. It turned out that during rapid economic and social changes, the development of technical and social infrastructure became one of the drivers of development. In the conditions of the market economy in Poland, two important areas related to the functioning of the public sector have come to the fore: quantification of objectives and tasks necessary for the proper functioning of the state and society and ensuring efficient sources of financing these tasks. In this paper the aim of the research was to analyse and assess the financial situation of municipal territorial self-government units in Poland in 2007-2015. The research results clearly indicate the existence of differences in the level of budget revenues between differentiated territorial self-government units in the years 2007-2015. In that time the budget revenues of communes increased and significant positive changes in the budgetary situation of municipal local government units took place, in almost all regions these incomes doubled. This increase was accompanied by persistence of disproportions between less developed regions and regions that were economically and socially developing faster. In the discussed period, we had to deal with the improvement of the income situation of the budgets of local government units, with the simultaneous increase in the differences in the level of income with all the consequences associated with this for future development.

Keywords: public finance, local development, financing of investment, public services

\section{Literatura}

1. Diamond J., Budget System Reform in Emerging Economies. The Challenges and The Reform Agenda, IMF, Washington 2006.

2. Flynn N., Public Sector Management, Sage Publ., London 2007.

3. Hou Y., Local Government Budget Stabilization: An Introduction, [w:] Local Government Budget Stabilization: Explorations and Evidence, red. Y. Hou, Springer International Publ., Cham 2015. 
4. Jarosiński K., Maśloch G., Analiza i ocena wskaźnika PPS w wybranych miastach Unii Europejskiej wobec celów rozwoju zawartych w Strategii Europa 2020, [w:] Zarządzanie i finanse podmiotów sektora publicznego, pr.zb. pod red. K. Jarosińskiego, „Monografie i Opracowania" nr 595, Oficyna Wydawnicza SGH, Warszawa 2014.

5. Jarosiński K., Opałka B., Maśloch G., Grzymała Z., Financing and management of public sector investment on local and regional levels, PWN, Warszawa 2015.

6. Knox Lovell C.A., Performance Assessment in the Public Sector, [w:] Efficiency in the Public Sector, red. K.J. Fox, Kluwer Academic Publ., Norwell, Massachusetts 2002.

7. Kosikowski C., Naprawa finansów publicznych w Polsce, Wydawnictwo Temida2, Białystok 2011.

8. Parr J.B., Regional Economic Planning: Learning from Past Experience, [w:] Public Investment and Regional Economic Development, red. D. Felsenstein, R. McQuaid, P. McCann, D. Shefer, Edward Elgar Publ., Cheltenham, UK 2001.

9. Phelps M.G., Changing Costs of Public Services, Office for National Statistics, Newport, South Wales 2009. 